capital and the construction undertaken by British line nowis point offers no insuperable dificulty and the is to be prolonged through Rhodesia and connected with the completed railway from Beira to Salisbury. It is also reported that an agreement has been made
between England and Purtugal for the construction of a harbor at the wouth of the Kunene, and the building of a railway from thence eastward to Buluwayo. In by the German government to extend from the mouth
of the river $S$ wakop to Windhock, and 60 miles of this road have been in operation since April. 1898

The most important portion of the railways of Africa however, are those in the British Cape Colony, the Orange Free State, and the Transvaal Republic. These extending from Cape Town to Buluwayo, and beyond to Salisbury, where it connects with the Portugues line from Beira. Branch lines also connect with Port Elizabeth, Port Alfred, and Port Natal. Johannesburg and Pretoria are connected with the Indian Ocean by two railways, one running to the Portuguese harbor of ban, in the British colony of Natal.

It is in connection with the Egyptain railway up the Nile Valley frow Alexandria to Cairo, and beyond to Khartoum, that the proposed Cape-to-Cairo route has been considered, the whole being intended to form a mixed rail and water route through the whole length of the continent. Herr Claus gives a detailed tabula route his map showing very clearly the completed

and proposed portions.
In British East Africa, an in portant piece of railway is being constructed from Mombassia to Port Victoria on the Victoria Nyanza, this road being wore than 600 miles long. passifover an elevation of more than 8,500 pleted it will enabledirect communication to be mad from the 25,000 square miles of area of the Vietoria Nyanza to the sea.

At the beginning of 1899,125 miles of this road were in operation.

Herr Claus discusses briefly a number of minor projects for rail ways from points on the coast into the in the general opening up of the continent, but for further information respecting these
his excellent map and article.

\section{AUTOMATIC LUBRICATOR}

$W_{E}$ illustrate an ingenious automatic lubricator intended for the supply of solid lubricants, which has recently been brought out by the Aktiebolaget Lubrikator, of Garf varegatan 13 , Stockholin. Solid lubri- there is, in the first place, a certain liability of sticking due to grit or other foreign body finding access to the interior; and, secondly, the rate of supply varies the feed is positive, and can be altered within wide limits as may be needed by particular cases. The feed is given by a plunger above the grease in the cup, fed

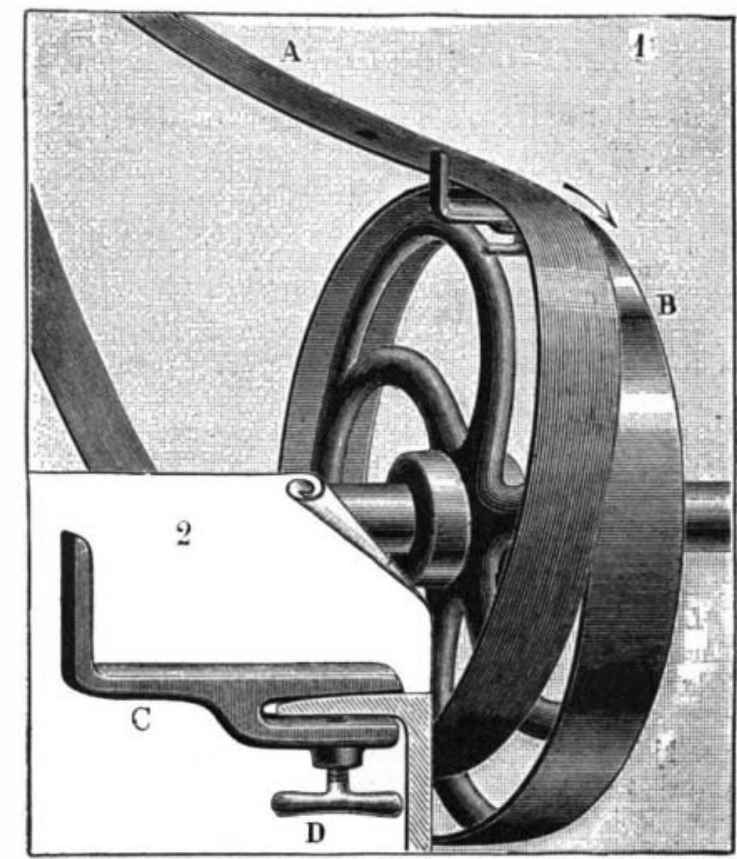

DEVICE FOR MOUNTING DRIVING BELTS.

1. Arrangement apon the palley. 2. Details of the hook.

down by a screw which is turned round by the ratchetwheel shown above the cup in figure. The driving friction feed wheel clearly shown in Fig. 2. This wheel
f is in turn rotated by a swinging arm, carrying a friction pawl as shown, and having at its free end an ecThe eccentricity of this roller can be varied at will, and consequently a greater or lesser feed given to the oreover, being extensible, provides an additional means of regulating the feed,
since it is obvious that the longer the arin the less the
DEVICE OF MOUNTING DRIVING BELTS

IN order to transmit the motion of the engine to the machines that it is desired to set in motion, it is of ten of very large size, which have to be mounted bes pulleys. Now, in most cases, the operation of mounting is performed by means of a cord provided with a slip-noose ; but great care must be taken to loosen the cord at once as soon as the engine is started. It may happen, however, that the cord will not slide easily, and in such a case the belt may be damaged. In realit. the operation is attended with many dangers. of M. J. B. David, at Boen, having had considerable experience with such inconveniences, has devised an apparatus that permits of easily mounting belts without any danger, and which is represented in the accompanying engraving. It consists of a metallic rod, $C$, bent upward at one of its extremities in such a way the device is formed a recess for the reception of the edge of the pulley rim, to which the apparatus is
fastened by means of an adjusting screw. $D$. In order that the apparatus may operate properly, the distance of the vertical arm of the rod to the external edge of the belt

By means of this little device, which is easily constructed, a belt may be very readily put in place. The neans of is first fastened to the rim of the pulley by then the engine is started and the belt slides upon the pulley at once. The pulley may unake several revolucions with the apparatus attached without the latter interfering with the belt in any way whatever. indebted to La Nature.

THE CARE AND HANDLING OF INFL AMM ABLE SIJBSTANCES.

By Joseph F. Hostelley.

Pharmacies are not infrequently visited by fire, which can of ttimee be attributed to injudicious storage stances. On the part of a great number of phar there is a distressing disregard for the dangerous nature of some of the substances carried in stock, elements that have a great affinity for fre. Eternal vigilance is

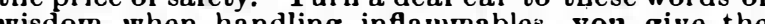
waily newsgatherers pabulum for their gazettes. It is his own actions in this regard, but he must keep a watchful eye upon the movements of his assistants.
If the "boy" be of a grammar-school age, it behooves

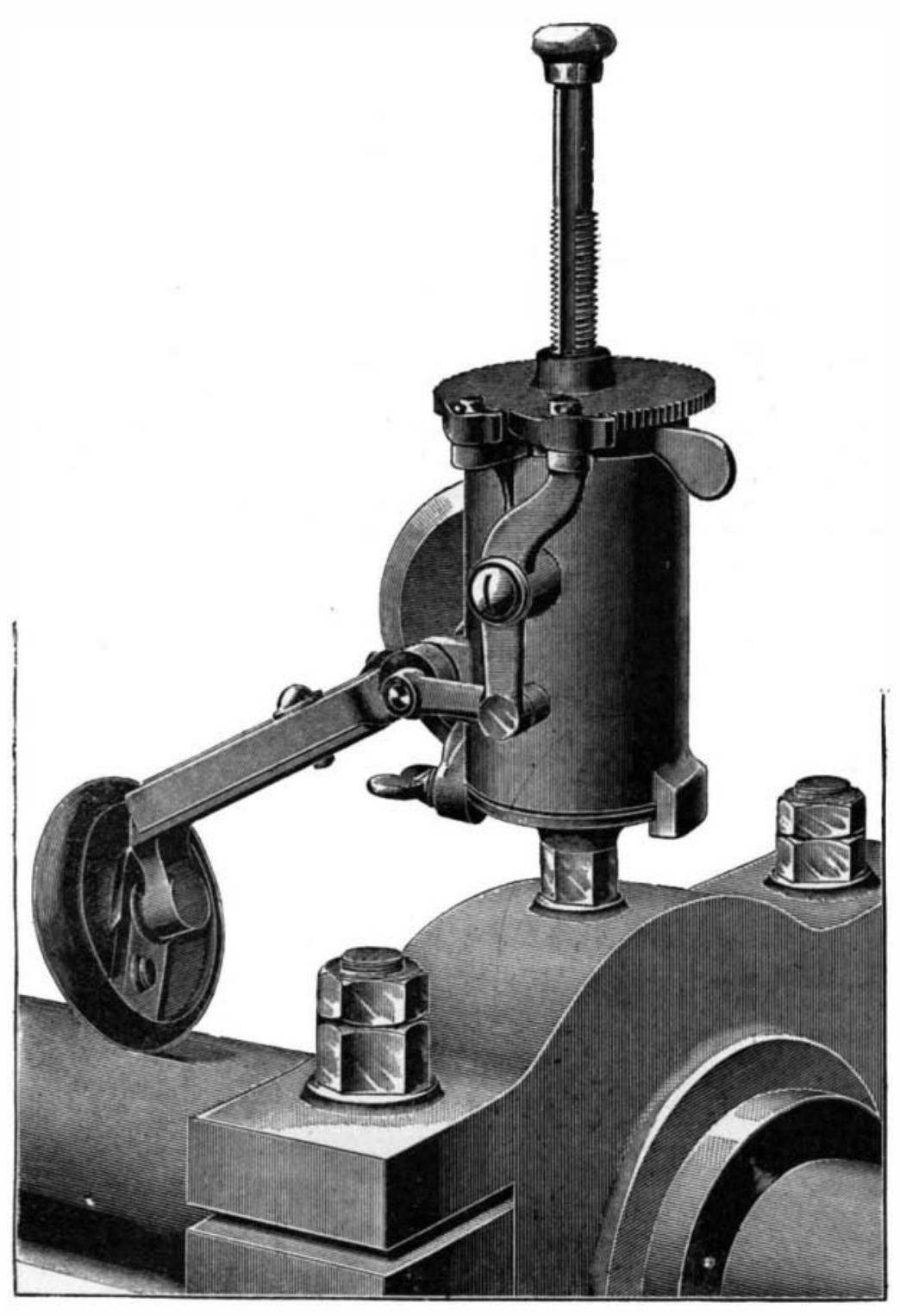

FIG. 1.

cleanly, economical, and excellent reducers of fric tion. As usually applied, however, there is a difficulty in insuring a continuous and regular flow of the cup is used, the cap has to be screwed down at frequent intervals, while the spring loaded lubricator tend to give a more copious feed of the lubricant when freshly filled than when nearly empty. With the grav.
ity feed lubricators, on the other liand, in which ity feed lubricators, on the other liand, in which a
rreight resting on the grease forces it on to the bearing
AUTOMATIC LUBRICATOR FOR SHAFTING.

feed with a given eccentricity of the roller. The feed , may add, works in a split nut, which can be opened when it is necessary to raise the plunger in
order to fill the cup. The refilling lis done from the hottom, the top of the cup being freed from the bottom portion by slacking the wing nut shown. In ordinary work, one charge of lubricant will last 300 to 400 hours. The rate of supply is, of course, unaffected by a rise of being a positive one.-Eagineering.

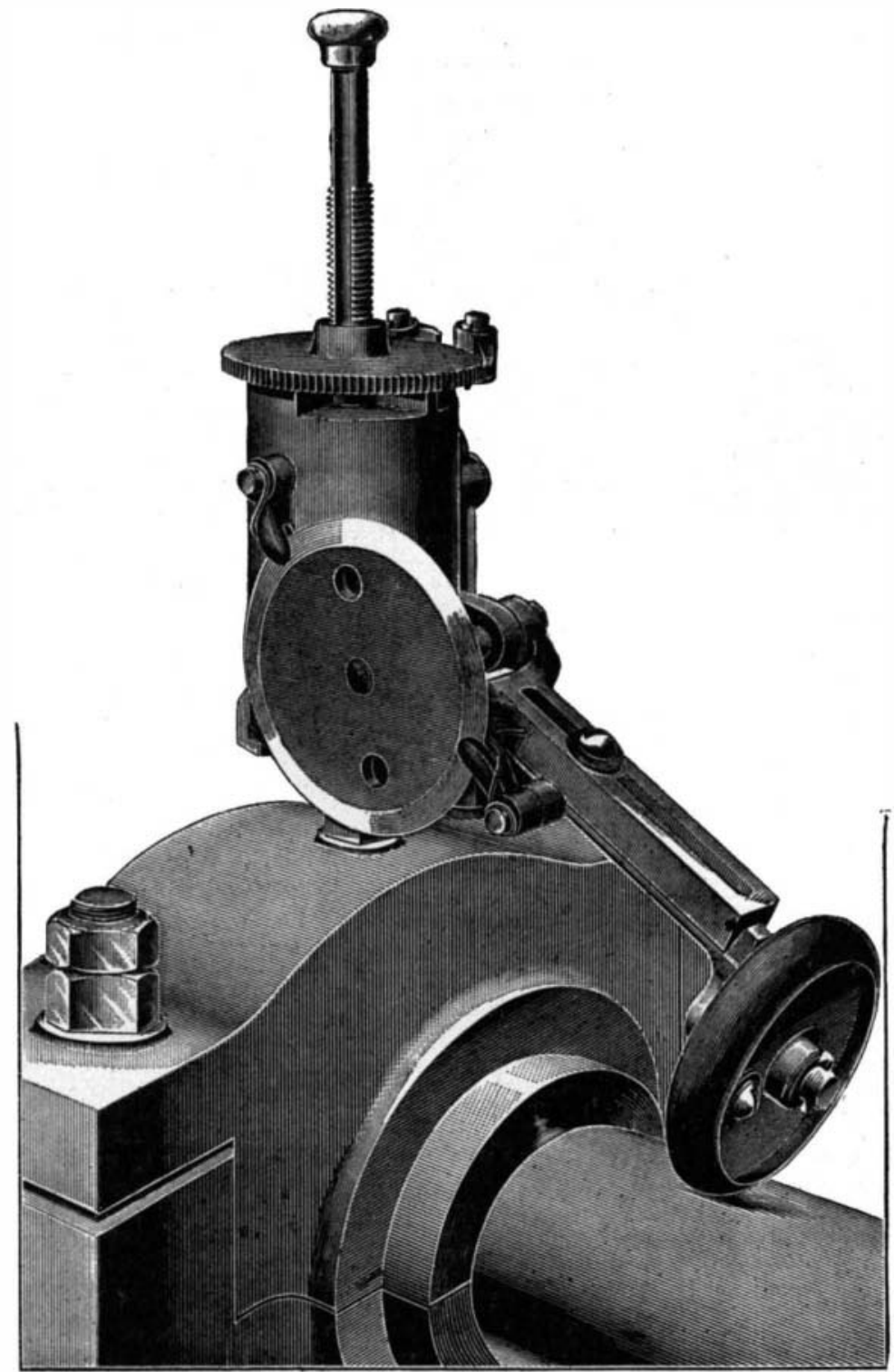

FIG. 2.

every other attache of the pharmacy to be his ani their own guardian angel, so to speak. The pharmacellar or "back room" in which are stored in flammables and explosives, at his own sweet will, is court ing a conflagration, commercial ruin, and possibly bodily harm to one or many persons. The same is trize of him who hands a lamp or candle light to an etruotions to "Junt put it in the oellar; sou know 
where it goes," or to "look about; you'll find some fanstem in the handling of inflammable or explosive substances and compounds is powerful in preserving the person and property from injury, and insuring to that of ten follow reverse methods. There should be a definite locality in the establishment for keeping
inents of this type, and here and nowhere else, eacl
:tuil every one should at all times be found. No putting benzine in the rear of cellar, a vial of chloroform
neir the street, exit, and a vessel of phosphorus under
the stairs, with, possibly, ethers on a lower shelf in the "back room." Have that proverbial place for every thing in its place. Teach clerks the import of such a
regime. Concerted and conentrated effort along this exerts a potent influence toward the elimination of danger arising from scattered containers of inflaummables, one of which may happen to rest just in the proper position to be ignited by a lighted match dropped inadvertently, a spark from the heater, the cigar
of a careless worker, by mice gnawing matches, or by In a sepuliped lamp.

In a sepulcher one treads with a we because the very
appearance of the tomb impels a reverential step. Now, if somewhere about the establishment there was
a special freproof apartment, a room distinct and disinctive wherein to store the commodities of which we write, a foot would not be stepped within its threshold
without a realization of the dread nature of its contents. Its peculiar construction and comparative iso sity for cautious movements and prudence. Such a department would necessitate a greater or lesser de its services, significantly valuable, merit this expendiits services, significantly valuable, merit this expendi-
ture? Surely an ounce of prevention is worth a pound
of cure. Would it not be far wiser, then, to spend few dollars on such a precautionary measure, than to lose hundreds by a fire that might have been averted If not, then the whole system of property and life in-
surance is a fallacy, and insurance corporations, frauls.
Let us tell a succinct story brought to mind by several actual happenings: There is a demand in the where in the cellar inthe time of day is dusk is some the cellar is poorly lighted or the day is gloomy; a below among a heterogeneous list of items; th search consumes some minutes, probably because of ject of the quest does not desterialize, haste steps prudence; the movements of the light becoms
erratic; there is a flash, a flame, and an after investierratic; there is a fash, a flame, and an after investi-
cation, which finds that misplaced item of stock the
cause, one way or the other, several hundred dollars cause, one way or the other, several hundred dollars
loss the effect. Which, think you, would have been the cheaper, a special fireproof department for such

The whereabouts of the apartment we suggest would
naturally, be governed by circumstances, by the facilities at command. Ifany impulses suggest the cellar a a good and usually convenient locality wherein inflammables will most likely be beyond the casual fire-brand
or that "defective flue" so often sinning and being because of the earth or cement floor and the stone walls. because of the earth or cement foor and the stone walls.
Here a stone or brieck and mortar vault could be de-
signed. A corner affords the advantage of two bound aries or walls ready constructed. Little wood should of sheet iron would be preferable. A pane of glass may should be seen. Interior shelving could be of board covered with asbestos cloth or tin, or of heavy, plate glass. If practicable, an incandescent globe should
constitute the means of affording light therein. If a hand illuminant be necessary, a tallow or wax candle seems commeudable because, in itself, there is not, as in
the case of the lamp bowl, a substance to greatly en-
danger surrounding objects, if it be overturned. candie lantern is a clever device. A gas jet has to it discredit the heat generated by the ignited gas.
A fair substitute for a fireproof vault would be a capacious closet or room of boards, built into one corner of the cellar. This would be less expensive than
the former. Boards for its construction could be obtained from packing boxes. Many of those from botthe cases are three feet some inches in length. As the are to be covered and protected by asbestos cloth
tin on both sides, they would require no planin When completed, both interior and exterior wood work
of closet should be completely and fully hidden be neath a coating of non-combustible material. She
ing should be like wise made insusceptible to flame. will be found such inflammables as the following Alcohol, benzine, chloroform, carbon disulphite, ether
acetic ether, spirit of nitrous ether, ethylic aldehyde, ethyl bronis, ethyl chlorid, phosphorus, etc. Lique fied gases in cylinders, such as carbonic acid gas, oxy
gen, etc., should be kept herein; also light petroleuin gen, etc., should be kept herein ; also light petroleum
oil for supplying lamps for illuminating or stoves for heating. Powders, etc., for pyrotechnic displays on the
Fourth of July, to herald the election of certain men
to then to public office, and for diverse local celebrations. Be-
tween festivities these fireworks may be preserved in this compartment for inflammables.
No matter what may be your method of storing in violation of which is a pharmaceutic misdemeanor demanding a severe censure-never to remove the stopper from a vessel containing such a dangerous substance,
in the neighborhood of a lamp, candle, or gas flame. During the hours of sunlight, such a substance is not 1o be transferred from one container to another in a
liark roo 11 or cellar, where an unsafe medium sheds liwht. Let the vessel and its desired contents be taken where the sun may aid the eye and hand to pour,
weigh or measure. Insist that, with exceptions really
unavoidable. all such duties be done before nightfall. The replenishing of shelf bottles should not be delayed be filled during the early hours. Procrastination in
these matters is fraught with danger. Excelsior, paper waste, hay, or other matter greedy to grasp a spark or
flame, must not be allowed to lie on the cellar floor in loose piles. Hot ashes should never be deposited in a
barrel, cask, or box of wood; many fires are caused by
ignoring this precaution. Care should be exercised in ignoring this precaution. Care should be exercised in suming rubbish in the heater, the latter should not be
left alone many minutes. This brings us to a consideration of fire-extinguishers
left applicable to the pharmacy. There are patent ones galore. The possibilities of carbonic acid are proverbial. in potent properties as a fre fighter may be util-
izeor of the wrescription department or "back room." a cylinder of carbonic acid is set securely upon a shelf at trolled easily by one above the trap in the floor or by protection of two departments of the store. To the cylinder is connected a section of rubber tubing or froml above and below. Here is another idea: A fresh ped, a spigot affixed to it, a hose attached, to be hung as described for tank of acid, and the trap cut in floor. Such a scheme as this, or that preceding. secures an of the hour of need. This end might be furthered by distributing about the premises, in readily accessible
positions, syphons of soda, or hand grenades. The
latter are easily prepared by the pharmacist from familiar formulas and several flasks.

The peculiar affinity calcium carbide has for moisture, and the specific effects of such an equation, should not be overlooked. Keep calcium earbide in a dry is destined to pass out of mind. But don't let it rest phosphorus irnites Accidents have resulted by forgeen and unfortunate events. Whatever may be the demand upon your time, never fail to recork a vesse containing an inflammable, immediately after hand-
ling. If any be spilled on the floor or over other oband inform other attaches of the pharmacy of at once dent, that they may be cautious for some little time
after when approaching this locality with a light in hand. of benzine. A caution label may be overlooked; ver-
bal advice is potent and it seens to always have an the cellar, at the foot of the steps to street where " wagon and dray drivers may see, hang this placard

ber its purport yourself.
Let the pharmacist, in the matter of protecting his
property from fire, learn to be cautious, painstaking. cystematic. Teach the principle of pruclence to you cused of timidity than temerity.--The Pharmaceutical

\section{TRADE SUGGESTIONS FROM UNITED} STATES CONSULS. Agricultural Implements in Eastern Brazil.-Consul
Furniss, of Bahia, on January 17, 1900, writes to an Illinois company as follows:
Very few agricultural implements are used in this district. Some time ago, I made a trip to the consular distriet, where coffee, sugar cane surprised to note the entire absence of modern agricul tural implements. The ground is prepared for plant ing by turning it up with a spade, but more often with where the soil is particularly hard. A crop once coffee being full of weeds and other vegetation and a cultivation that is done (more particularly with tobaceo) is effected with a broad hoe, of the type long ago used In many parts a plow is unknown; in fact, I can fin was the sugar-cane section, under the management of an English conipany, and the plows brought out hav

not be induced to use them.
Such farm implements as seeders, harrows, planters, drills, cultivator's, hay loaders, corn huskers, and the
like are enti.ely unknown here. Indeed, there could be no use for many of these things, because little in the way of grass or vegetables is raised, the supply bein toes from Portugal and possessions and Germar beans from Southern Brazil, Argentina, and a small quantity from the United States, though there is plenty of land in this

As Brazil is nearly as large as the United States, in speak as to the chances for the implement trad to this consular district. which includes the States of Bahia and Sergipe. I understand that in Rio Grande
do Sul and Santos they devote more attention to modrn farming.

The whole of the Argentine Republic offers a good American Buggies in New South Wales.-Consu Goding, of Neweastle, under date of January 16,1900
writes that through the personal efforts of that offiee introduced. By the outgoing uail there were ordered six different styles of buggies. The orders are each ac companied by a draft for the anounts. Mr. Godin buggies, etc., between the colony and the United

Colonial Training in Belgium.-Consul Roosevelt writes from Brussels, February $23,1900:$ in the Belgian
Kongo, this government is considering means of interesting the people in the subject of colonization. One Horticnltural School, at Vilvorde, of a special departfortune in the colonies. There will be practical demonstrations of the sort of buildings a settler must
construct and instruction in rules of sanitation. The cultivation of indigenous plants, as well as of European vegetables and plants, the best methods of gathering
crops and transporting thein to market where there is a dernand for them, and the way to treat the native population, from which the

Colonial School in France.-Consular Agent Harris, A colonial institute is to be opened in Marseilles to
a to prepare young men to fill positions in the French
colonies. Expeditions of students will be sent out at the expense of the State, and commercial houses will detailed reports. Instruction will be given in botany, zoology, natural history, colonial geography and his-
tory, etc. There will be a museum of plants, minerals, etc., so that the student may become acquainted with medicine to familiarize him with diseases peculiar to tropical countries. It is probable that arrangements
will be made for teaching Oriental languages. For grounds and buildings, the city of Marseilles has Openings for Americans in Nicaragua.- In answer to
inquiries by a New York correspondent (to whom the inquiries by a New York correspondent (to whom the on February 10,1900, sends the following information: As teachers and professors in government and other
schools in Nicaragua, there is really no opening for our young graduates. Salaries here are insignificant and
customs so different that Americans have never proved successful. The salary of a principal here is 50 pesos, successful. The salary of
or about $\$ 17$, per month.

American physicians and surgeons are successful
here, but no part of the world is more crowded with them than the large towns of Nicaragua. Hundreds of the native young men study medicine in the Unitel
States and return here to practice. They understand better their own diseases, custorns, and people than a foreigner could, and the inajority of the people prefer American dentist comes, he does a good business and can charge remunerative prices.
Engineers of all kinds are the most successful of any professional wen in these tropical countries. Very few employed by the government are foreigners. An en-
gineer's salary at the start is from 250 to 300 pesos ( $\$ 80$ to $\$ 100$ in United Staies gold) per month.
to 300 pesos ( $\$ 80$
. natives. The wives of officials, of planters, of lawyers, natives. The wives of offeials, of planters, of lawyers,
of doctors, and even of politicians, have their little
shopis and thus crowd every town with stores. Salaries for clerks are not worth the consideration of any foreigner.

The German Jute Industry. - Vice-Consul-Genera Hanauer sends the following from Frankfort, February 6, 1900 :
The number of spindles working up jute yarns has
increased from 73,226 in 1890 to 135.000 in 1899 . The increase in the import of raw jute las not kept pace a larger market in Germany. The annual production marks $(\$ 11,900,000)$ in value. The import of jute bags
having in late years largely increased, the German manufacturers are asking for a change in the tariff rates on the bags, so that in future jute bags importe pay duty. These manufacturers are now negotiating

American Wheat for Macaroni.-The Bureau of Foreign Commerce has received another letter from the wheat which was sent to France to be tested as to its fitness for use in the manufacture of nacaroni and
similar edible pastes. Mr. Simpson says, in part: similar edible paste's. Mr. Simpson says, in part:
It has been demonstrated beyond question that all
Northern Texas is perfectly adapted to the growth of the hard, glutinous wheats now in such great demand in France and Italy. The grain 1 transmitted through
your kindness to Consul Covert, of Lyons, upon analy.
sis shows the value of this hard wheat to Texas. With the port of Galveston now open, giving us easy access
to Marseilles, this wheat is calculated to revolutionize production here. through negligence, have mixed the hard and the starchy wheats, and we tind it almost impossible to obtain the pure hard grain. I did the best I could in in sending 5 bushels at your request to the Yaris Ex position, but all had soune grains of soft wheat in it wheat for seed, it would be but a few years before Texas would control
in this hard wheat.

Index to Advance Sheets of Consular

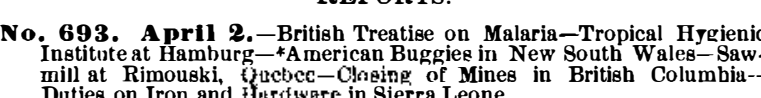

No. 694. A pril 3. - Minerals and Mining in Ecuador-*Agricultural
Inplemente in Eaatern Brazil.
No. 695 . A pril 4. 4 -American Ginseng in Cbina-Bee Raieng in

No. 696. A Ary 5. 5. Rubber in the Straits Settlements-Tubcr-
culosis in Norway.

o. 697. April 6. -Packing Evaporated Fruita for France-Litho-
graphic-stone Trade in Germany - ${ }^{-}$Colonial school in France -
"Colonial Training in Belgium.

698. Apr 11 7.-Cotton Goods in New South Wales-Financial
Conditions in Guadeloupe.

The Reports marked with an asterins (*) will be publisbed in the SCIEN-
FIC AMERICAN SUPLEMENT. Interested parties can obtain the oth

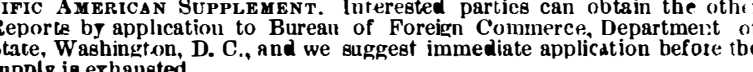

